\title{
Keeping NTFPs in the Forest: Can certification provide an alternative to intensive cultivation?
}

\author{
David S. Wilsey and Jeremy Radachowsky
}

\section{Research}

\begin{abstract}
North American and European florists import the leaves of various species of palms of the genus Chamaedorea to be used as foliage in floral arrangements and for use in Palm Sunday church services. Chamaedorea harvesting contributes to forest livelihoods in several regions of Mexico, the Petén region of Guatemala, and Belize. Such commercialization of NTFPs has long been advocated (as well as debated) as a means to integrate forest conservation and rural development objectives. Yet, extractive production system models and experience suggest that system dynamics are not sufficiently stable over time and space to reconcile these objectives. This paper considers NTFP certification as an intervention to promote the longterm reconciliation of integrated conservation and development objectives in a working forest context. Specifically, we consider palm harvesting in the community forest concessions of the Maya Biosphere Reserve in order to address the fundamental question: how might certification ensure that NTFP extraction remains an ecologically sustainable and economically viable source of income for communities in working forests? We consider the opportunities and challenges related to NTFP commercialization and certification, provide an overview of existing certification options, and conclude with a modest proposal for a new generation of certifications.
\end{abstract}

\section{Introduction}

The conservation of tropical forest resources has the often unrealized potential to benefit local and non-local populations as a source of useful and marketable resources, as well as through the provision of multi-scale environmental services (Myers 1983). Commercialization of nontimber forest products (NTFPs) has been promoted as a strategy for the reconciliation of conservation objectives and the livelihood needs of forest-based populations (Arnold \& Ruiz-Pérez 2001, Nepstad \& Schwartzman 1992,
Neumann \& Hirsch 2000). Ostensibly, commercialized NTFPs have the potential to contribute to the integration of these objectives by increasing the economic value of intact forest to local inhabitants, providing an incentive for conservation. Proponents of extraction-based conservation models have been strongly cautioned that the economics of extraction suggest that, over time and space, the harvest of naturally-occurring populations is replaced by cultivation and/or substitution with less expensive alternatives (Dove 1993, Homma 1996). As NTFP production transitions from forest to farm, the integrated livelihood and conservation benefits associated with harvest are likely to diminish. Certification has been promoted as a counter-measure to this trend and a means to retain livelihood benefits for communities committed to forest conservation. Neither sustainability standards nor price premiums, however, will be of much importance to forest communities if overall demand for extracted forest products declines precipitously in the wake of increased production in external plantations. This paper is concerned with the dynamics of NTFP extraction activities as they relate to the long-term realization of integrated conservation and development objectives in working forests. Thus,

\section{Correspondence}

David S. Wilsey, School of Natural Resources and Environment, University of Florida, Gainesville, 103 Black Hall, P.O.B. 116455, Gainesville, FL 32611, U.S.A. dwilsey@ufl.edu

Jeremy Radachowsky, Department of Wildlife Ecology and Conservation, University of Florida, Gainesville, FL 32611, U.S.A. tapir@ufl.edu

Ethnobotany Research \& Applications 5:045-058 (2007) 
we consider the fundamental question: how might certification ensure that NTFP extraction remains an ecologically sustainable and economically viable source of income for communities living within or adjacent to "working" conservation areas?

Specifically, this paper reflects on certification of Chamaedorea spp. palms as a means to sustain integrated conservation and development objectives in the community forest concessions of Guatemala's Maya Biosphere Reserve (MBR). By focusing on Chamaedorea palms in the $M B R$, we are attempting to distill from the broader discussion of extractive production systems and NTFP commercialization those factors that threaten this important product's role in the region's integrated conservation and development strategy. We begin with a general discussion of the opportunities and challenges faced by NTFP commercialization and the emergence of certification as a potential commercialization option. Chamaedorea palms are then presented as a case of a successful NTFP, but one with an uncertain future. Existing and emerging production systems are discussed. We then present Chamaedorea harvest in the context of the community forest concessions of the MBR and consider the implications of production system dynamics. Finally, we review existing certifications for NTFPs and evaluate each against the objective of retaining the livelihood option of wild-harvest in the forest concessions. We conclude with an assessment of the likely future of Chamaedorea extraction in the MBR and with a proposal for a new generation of certification designed for integrated conservation and development objectives.

\section{NTFP commercialization}

A complete discussion of the myriad issues and challenges related to natural product commercialization is beyond the scope of this article, but it is important to highlight the contours of the discourse. Four general classifications of potential concern tend to be found in the NTFP commercialization literature (Arnold \& Ruiz-Perez 2001, Browder 1992a,b, Crook \& Clapp 1998, Dove 1994, Neumann \& Hirsch 2000, Richards 1993, Ros-Tonen et al. 1995, Shanley et al. 2002, Ticktin 2004). Ecological concerns relate to the potential for negative consequences of commercialization with respect to NTFP populations, the broader biotic community, and the greater ecosystem. Economic concerns relate to the potential failures of commercialization strategies stemming from such factors as supply and demand characteristics, calculated value versus net benefits, and economies of scale, to name a few. Socio-political concerns focus on the contextual elements of NTFP harvester groups and regions such as resource tenure and rights, effects on gender roles and on the broader contribution of NTFPs to rural livelihoods. Often there can be unintended and disruptive effects of NTFP commercialization. Finally, concerns relate to the incompatibility of existing forms of forest management and potential ob- stacles to the changes that may be necessary in order for commercialization to succeed. In practice, many of the issues presented within these distinct classifications are interconnected.

In addition to these four classifications, the "causal" factors for failure of commercialization efforts tend to be of three types (Neumann \& Hirsch 2000). First, market-related factors may create conditions favorable to particular types of resource exploitation, namely over-exploitation. Second, the institutional conditions associated with commercial harvest may differ significantly from existing conditions and customs. Third, the biological attributes of commercialized NTFPs play an important role in the potential outcomes of commercial harvest.

Critics of commercialization as a means to the integration of conservation and development objectives assert that commercial resource extraction represents an unstable base due to the many possible combinations of the reasons mentioned above (Belcher \& Schreckenberg 2003, Browder 1992a,b, Dove 1994, Homma 1996). The challenge of NTFP commercialization efforts has been to identify conditions for successful extraction that contribute to the conservation of forests and increased incomes for forest people (Ros-Tonen et al. 1995). Certification, in the broadest sense, represents a commercialization adaptation intended to address the socio-political, ecological, and economic failings that have been empirically observed in ongoing NTFP commercialization efforts.

\section{NTFP certification}

Certification is a process through which transnational networks comprised of diverse actors set and enforce standards for products and production processes (Dankers 2003, Mendinger 2003). The certification process includes two important public roles (Mendinger 2003): defining acceptable or appropriate behavior and establishing mechanisms to enforce product or process standards. Certification programs are 'market-based' in that they "seek to achieve their goals by restructuring producers' relationships to consumers through markets" (Mendinger 2003:266). The use of certification as a forest policy tool is relatively new (Overdevest \& Rikenbach, in press, Shanley et al. 2005, Viana et al. 1996). NTFP certification has emerged as a prospective solution to the myriad ecological, economic, and social challenges associated with commercialization (Shanley et al. 2002, Shanley et al. 2005, Viana et al. 1996), but support has waxed and waned due, in part, to the significant challenge of creating broadly applicable certification guidelines for an extremely diverse set of products and production systems. Moreover, early efforts suggest that certification represents a viable strategy for only a limited subset of "charismatic" NTFPs with high profiles and international markets (Laird \& Guillén 2002). Although certification was described nearly 15 years ago as "key" to the integration of conservation and 


\section{Wilsey \& Radachowsky - Keeping NTFPs in the Forest: Can certification provide an alternative to intensive cultivation?}

development through extractivism (Clay 1992), NTFP certification remains in its infancy (Shanley et al. 2005).

Numerous opportunities and challenges have been identified with NTFP certification in general (Anderson \& Putz 2002, Mallet \& Karman 2001, Pierce 1999, Pierce et al. 2003, Viana et al. 1996). As a form of commercialization, efforts are likely to encounter most, if not all of the ecological, economic, and social challenges described above. New and different benefits and costs (opportunities and challenges) also emerge that relate to the increased transparency and formality of the terms of production and/ or trade. Price premiums, improved market access, environmental sustainability, and social justice are perhaps the most frequently cited benefits of certification (Shanley et al. 2002, Simula 1996, Viana et al. 1996, Walter 2002). Other benefits include increased efficiency, organization, transparency, accountability, safety, and education (Overdevest \& Rickenbach, in press, Shanley et al. 2005). Foremost among the challenges posed by certification is the paucity of biological information for the multitude of NTFPs as well as the numerous and significant costs to producers in an uncertain demand environment (Kiker \& Putz 2002, Shanley et al. 2002, Simula 1996). Nevertheless, some argue that the key challenge facing rural forest communities is not whether to participate in global processes (i.e. commercialization), but how to do so in ways that provide for sustainable growth (Fitter \& Kaplinsky 2002). The evolving concept of NTFP certification represents one important voice in this ongoing dialogue.

\section{Chamaedorea: a commercial success}

Chamaedorea palms are generally regarded as a commercially successful NTFP. Since the mid-twentieth century, North American and European florists have imported the leaves of various species of palms of the genus Chamaedorea, to be used as decorative foliage in floral arrangements and for use in Palm Sunday church services (CEC 2002). Chamaedorea palms occur in the forest understory in Mexico, Central America, and northern South America, often a dominant component. At least seven species (C. elegans, C. ernesti-augusti, C. oblongata, C. radicalis, C. seifrizii, C. tepijilote, and C. quetzalteca) are utilized by the cut-greens industry, the vast majority of leaves having historically been harvested from naturally-occurring populations in Mexico, Guatemala and, to a lesser extent, Belize. Although the profitability of palm leaf imports peaked during the 1960s, Chamaedorea greens remain an important commercial product and a source of income for forest dwellers.

Chamaedorea harvesting continues to contribute to forest livelihoods in several regions of Mexico (CEC 2002, Endress et al. 2004a, Jones \& Gorchov 2002, Santos et al. 2006, Zajfen 2005), the Petén region of Guatemala (CEC 2002, Dugelby n.d., IRG 2006, Litow et al. 2001, Nations 1992), and to a lesser extent in Belize (Bridgewater et al.
2006, Pickles 2005, Porter Morgan 2004). In particular, palm harvest is an important source of cash income. The activity has been reported in many protected areas including Maya, El Cielo, Monte Azules, El Ocote, La Sepultura, and El Triunfo Biosphere Reserves. Because the ecological impacts of palm harvest are minor compared with other land use alternatives, it is thought to further overall forest conservation and sustainable resource management (see Box 1). The emergence of external plantation

Box 1. Sustainability of Chamaedorea extraction

It would be easy to mistakenly conclude that NTFP harvesting represents the sustainable use of a forest resource because harvest seldom results in the death of a plant. Although leaf-cutting does not directly kill individual Chamaedorea plants, high harvest intensities coupled with slow growth rates and sensitive reproduction may threaten the long-term viability of individuals and wild populations (Porter Morgan 2004). Results vary by species. In a controlled study of C. tepejilote, Oyama et al. (1990) showed that defoliation did not have significant short-term effects on mortality or reproduction. More recent studies of $C$. radicalis show that harvest increased plant mortality and reduced growth and fruit production (Endress et al. 2004a,b, Endress et al. 2006). However, even intensely harvested areas appear to maintain stable populations. In contrast, a study of $C$. oblongata in one MBR forest concession concluded that harvesting led to decreased population densities of more than $2 \%$ among juveniles and $13 \%$ among adult plants in a single year (Radachowsky \& Ramos 2004) - declines occurring in areas of extraction while populations remained stable in areas without harvest activity. It is possible that modest conservation activities, such as not completely defoliating individuals, and protecting large female individuals may offset many of the negative impacts of leaf harvest.

While Chamaedorea populations may be resilient to some level of harvest, low prices and scarcity of market quality leaves make it difficult for harvesters to meet livelihood needs. Low prices and sales based on quantity (versus quality) promote over-harvesting. The percentage of leaves that are harvested and subsequently discarded can be extremely high, up to $76 \%$ in some instances (Radachowsky \& Ramos 2004). The loss associated with quantity-driven harvesting is unnecessary, but is perpetuated by the current procurement system. Contractors pay for quantity, rather than quality - losses being factored into the price - and thus create an incentive for harvesters to cut indiscriminately in the shortest time possible. Moreover, since prices are so low, harvesters have little option but to harvest leaves they know will never make it to market in order to meet quotas. 
production of Chamaedorea threatens the livelihoods of harvester communities and may, therefore, result in increased forest degradation as people seek alternative income sources that are likely to be more destructive than Chamaedorea harvest.

\section{Production systems}

This section describes the Chamaedorea production systems presently meeting the bulk of market demand and considers others that may emerge as competitive alternatives. These systems represent the full spectrum of present and future palm production and, given the assertion that production systems emerge in response to prevailing local conditions (Belcher et al. 2005), have important implications for future production in working forests.

\section{Wild-harvest of natural populations}

NTFPs collected from forests with little to no structural transformation and naturally-occurring and regenerating populations can be considered wild-harvested (Belcher et al. 2005). In a study of divergent cases of NTFP production systems, Belcher et al. (2005) found that wild-harvest systems tend to occur in areas of low-level human population and infrastructure, tend to be male-dominated, and tend to require low labor and return low yields per unit area. Resource degradation and diminished supply are common in areas where wild-harvest has been occurring for an extended period. The vast majority of Chamaedorea leaves purchased today in the US and Europe come from wild-harvested, naturally occurring forest populations in Mexico and Guatemala.

\section{Cultivated populations}

Cultivated populations occupy the opposite end of the production system continuum. To be considered cultivated, individual plants must be deliberately planted as seeds or seedlings (Belcher et al. 2005). Once seed propagation and domesticated plant cultivation has been incorporated into the production system, several specific management options may exist, depending on the particular characteristics of the NTFP. Belcher et al. (2005) found cultivated systems to be associated with the highest levels of population density, infrastructure, and economic development. Yields in cultivated systems are high, as are incomes, and both typically exceed average local figures. With regard to Chamaedorea, agroforestry systems and plantations are expected to garner the most attention in coming years.

La Flor de Catemaco provides an example of a successful agroforestry production operation located in the buffer zone of the Las Tuxtlas Biosphere Reserve in Veracruz, Mexico. Established in 1989, Flor de Catemaco is comprised of 154 ha, of which 90 are dedicated to export market production of Chamaedorea palm. Operating with the mission to "save our forests and fallows," Flor de Catemaco retains original forest canopy as shade for the sunlightintolerant palms. Understory vegetation is cleared and replaced with Chamaedorea, primarily C. elegans. Approximately 170 individuals from the surrounding communities are employed to cultivate, transplant, and harvest the palm leaves. Both foliage and seeds are exported.

Artificial shade plantations have recently emerged as a system of palm production, notably in the region to the south of Guatemala's Maya Biosphere Reserve. In such systems large areas are enclosed by light filtering screen. Palms are intensively cultivated using seed scarification and other germination techniques, agrochemicals, and fertilizers to enhance foliage growth. Presently the palms are being cultivated with the intent to sell them for enrichment planting in forest patches and fallows, as well as agroforestry systems. Some screen plantations have also been constructed to accommodate mature plants, ostensibly to explore the feasibility of selling the foliage, but it is unlikely that present market conditions can support the cost of this type of production at the necessary scale. Nevertheless, the emergence of intensified production for enhancement of remnant forest patches and fallows outside the MBR represents an emerging production model that brings into question the long-term viability of the wildharvest system.

\section{Managed populations}

Managed populations occupy the expanse between wildharvested natural populations and intensively cultivated systems. In keeping with Belcher et al.'s classifications, managed NTFP populations exist within the forest and rely upon natural regeneration processes. However, in managed systems certain treatments may be undertaken to facilitate the germination or growth of individuals. In our experience with Chamaedorea harvest we have not encountered explicitly "managed" natural populations, yet it would be surprising if known populations and high-yielding harvest locations were not treated with special care. Nevertheless, to our knowledge there are no heuristic treatments applied to facilitate reproduction and growth.

Enrichment planting within and around naturally-occurring populations of Chamaedorea has been explored in areas of Guatemala where excess harvest has led to reduced abundance of market-quality palms. Enrichment planting goes beyond management as described above, and involves harvesting palm seeds, cultivating plants in an intensively planted seed bed, and transplanting the young individuals among and around wild populations. In time, mature plants would provide additional foliage for wildharvest while retaining the character of the natural forest. This system is presently seldom utilized, ostensibly due to open-access tenure and unknown survival rates of transplanted palms. Enrichment planting has the potential to be compatible with wild harvesting, but the costs and ben- 


\section{Wilsey \& Radachowsky - Keeping NTFPs in the Forest: Can certification provide an alternative to intensive cultivation?}

efits are unclear in today's uncertain market. Over time, the natural characteristics of this system would diminish, but the impact on forest structure and biodiversity would presumably be less than with an agroforestry approach and more in line with conservation objectives (Trauernicht \& Ticktin 2005).

\section{Chamaedorea extraction in the Maya Biosphere Reserve}

\section{The Maya Biosphere Reserve}

In Guatemala, most of the Chamaedorea is harvested from naturally-occurring populations in the Maya Biosphere Reserve (MBR) - a mosaic of protected areas in El Petén, the country's northernmost department. The MBR was established in 1990 to protect two million hectares of subtropical moist forest and savannah (Figure 1). The MBR is situated within the broader Maya Forest, a region with high levels of biodiversity and endemism, and the largest contiguous neo tropical forest north of the Am-

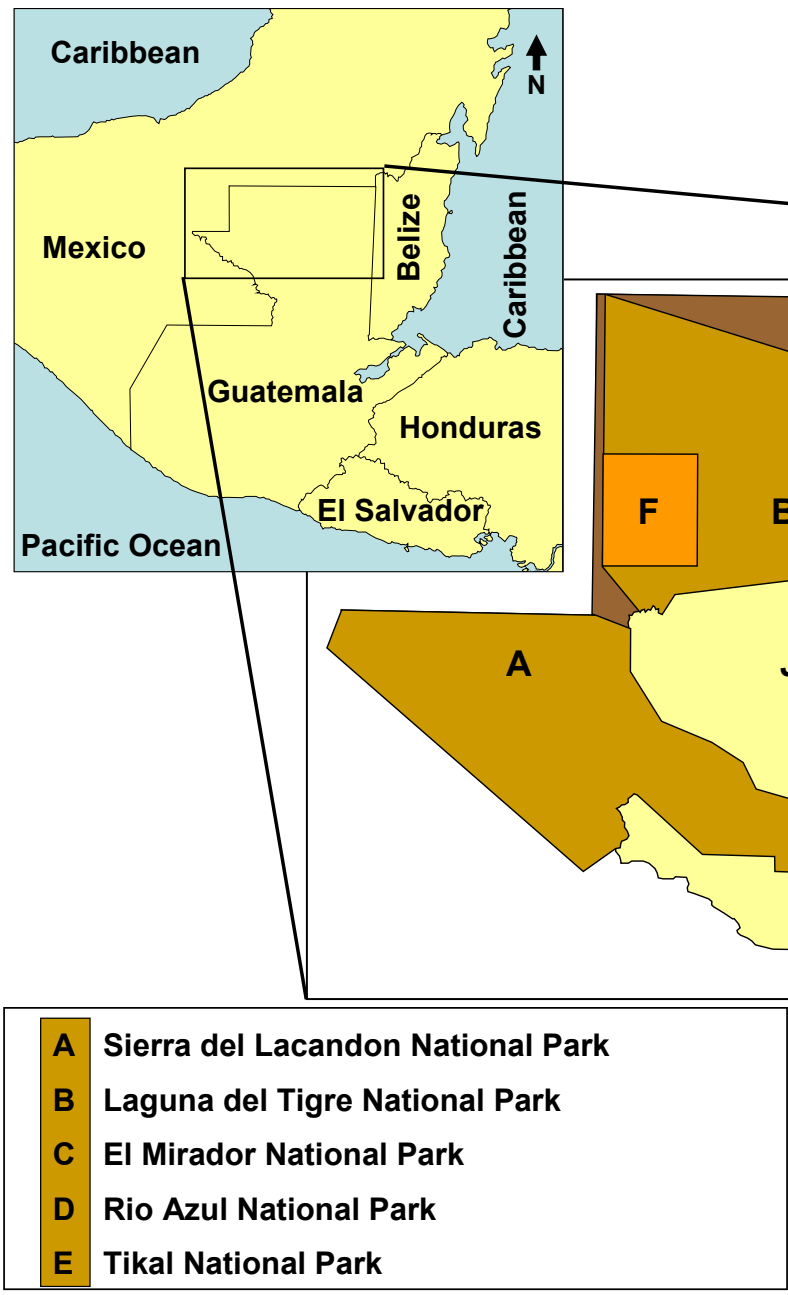

azon. In recent decades, this important cultural and biological reservoir has been threatened primarily by population growth (nine percent annually) driven by a variety of political and socio-economic factors (Fort \& Grandia 1999). Before the designation of the reserve, slash-andburn agriculture and logging threatened to wipe out the entire forest in fewer than thirty years (Sader 1999). A principal objective of the MBR is the prevention of this type of degradation and destruction through the integration of economic activity supporting local people and conservation measures to protect forest ecosystems.

In accordance with the United Nations Man and the Biosphere Program, the reserve is divided into three distinct zones. The Core Zone, covering $36 \%$ of the reserve, consists of National Parks and Biotopes. It is reserved for scientific investigation and low impact tourism. The Multiple Use Zone, covering $40 \%$ of the reserve, links the National Parks and Biotopes. This zone is an 848,440-ha "extractive reserve" within which only sustainable, minimallydamaging land use is permitted. The Buffer Zone, covering $24 \%$ of the reserve, forms a fifteen kilometer-wide band of highly-degraded habitat along the entire southern border of the reserve. Contrary to the ideal biosphere reserve design, in the MBR the core zone areas are distributed mainly around the reserve's periphery. This necessitates that the Multiple Use Zone must function as the de

Figure 1. The Maya Biosphere Reserve, El Petén, Guatemala. 
facto heart of the reserve in terms of maintaining largescale ecological processes. Consequently, the long-term success of the Maya Biosphere Reserve depends heavily on the conservation of the Multiple Use Zone and its constituent forest concessions.

\section{Community Forest Concessions}

In 1994 the Guatemalan National Council for Protected Areas (CONAP) began a process of transferring management of the multiple-use zone of the MBR to community-managed forest concessions as a legislative and management response to the increasing rates of deforestation in the Petén (Finger-Stich 2003). Currently, there are 14 concessions (12 community and two industrial concessions), ranging from approximately 25,000 ha to 83,000 ha, and covering nearly 800,000 ha in the multiple-use zone. Each concession was required by law to conduct a timber inventory, to develop a timber management plan, and to become certified for sustainable timber management. In fact, timber management in all concessions is currently certified by SmartWood, an accredited certification agent of the Forest Stewardship Council (FSC).

Timber, however, is only one component of a broader livelihood strategy that includes swidden agriculture and the extraction of commercial non-timber products such as Chamaedorea leaves (locally known as xate (sha-tay)), chicle latex (Manilkara zapota), and allspice (Pimenta dioica) (Litow et al. 2001). Benefits generated from NTFP activities represent an important livelihood contribution and, ostensibly, provide an incentive for forest conservation. In one forest concession, Uaxactún, $60 \%$ percent of men generate at least part of their annual cash income from xate palm harvesting (Radachowsky \& Ramos 2004). Moreover, a household survey undertaken by the Wildlife Conservation Society in the same community in 2005 revealed that households rank timber and xate equally with respect to contribution to household income (McNab, personal communication).

Together, the local benefits of timber and non-timber forest resources appear to provide an incentive for community members to protect their concessions against forest fires, illegal logging, and illegal colonization. Both NTFPs and logging operations create jobs for community members, thereby decreasing the likelihood of land-use practices less amenable to conservation objectives. In practice, the rate of deforestation and the incidence of forest fires have been significantly lower in forest concessions than in nearby national parks (Ramos 2004). Nevertheless, there is variability in conservation success amongst concessions; a few continue to suffer high rates of deforestation due to land speculation and immigration of families from other parts of Guatemala. As an expanding agricultural frontier intensifies pressure for the conversion of forest to cattle pasture, the future of other concessions is increasingly uncertain. It remains clear, however, that the success of conservation and livelihood improvement objectives depends directly upon the sustainable use of timber and non-timber resources.

\section{Production system dynamics}

The wild-harvest production system presently used by concessionaires in the MBR is effectively the same system that has been in place since the 1960s, when widespread commercialization of palms from the region commenced. Palm leaves are harvested by individuals or teams of harvesters contracted to work for extended sessions from a base camp located within a forest concession. Cut palms are sold in bulk to the contractors who organize and manage the camps, and who transport and, in turn, sell the unsorted palms to processing houses in Santa Elena, El Petén's largest urban center. Processing houses employ local wage-laborers to select palms based on size and quality; then sell sorted and packaged palms to exporters, who transport them to Guatemala City for export .

Expanding the frame of reference beyond the MBR, however, reveals an emerging trend toward Chamaedorea cultivation and production system intensification. This trend is consistent with Homma's theoretical model of extractive production system dynamics (Homma 1996, Figure 2) as well as empirical observation that NTFP often transition from forest to cultivation (Michon \& Foresta 1998). It is likely that the emergence of alternate, intensive production systems harbingers the beginning of the end for wildharvest production systems. Two reasons for this conclusion stand out.

First, agroforestry systems and artificial shade plantations are intensive production systems that generate predictable supply with consistent quality. An almost certain outcome of widespread, intensified Chamaedorea production will be an increase in the supply of high-quality palm leaves. Basic price theory suggests that an increase in supply precipitates a decrease in price, all else being equal. If intensive systems become more common, as present trends indicate, competition between wild-harvested stock and intensified production will increase. Homma's model is itself a testament to the negative impacts on extractive systems as cultivated systems achieve economies of scale (Figure 2). Typically, producers in commodity markets characterized by excess supply and low prices rely on volume to offset low margins. However, a volume strategy is less than ideal for a naturally-occurring and naturally-reproducing forest palm within a Biosphere Reserve, where conservation objectives are paramount.

A second reason is that if local conditions do, in fact, determine prevailing production systems (Belcher et al. 2005), communities living within and adjacent to protected areas (where much of Chamaedorea is harvested) will have a comparative disadvantage relative to locations unconstrained by conservation objectives. The dual conserva- 

provide an alternative to intensive cultivation?

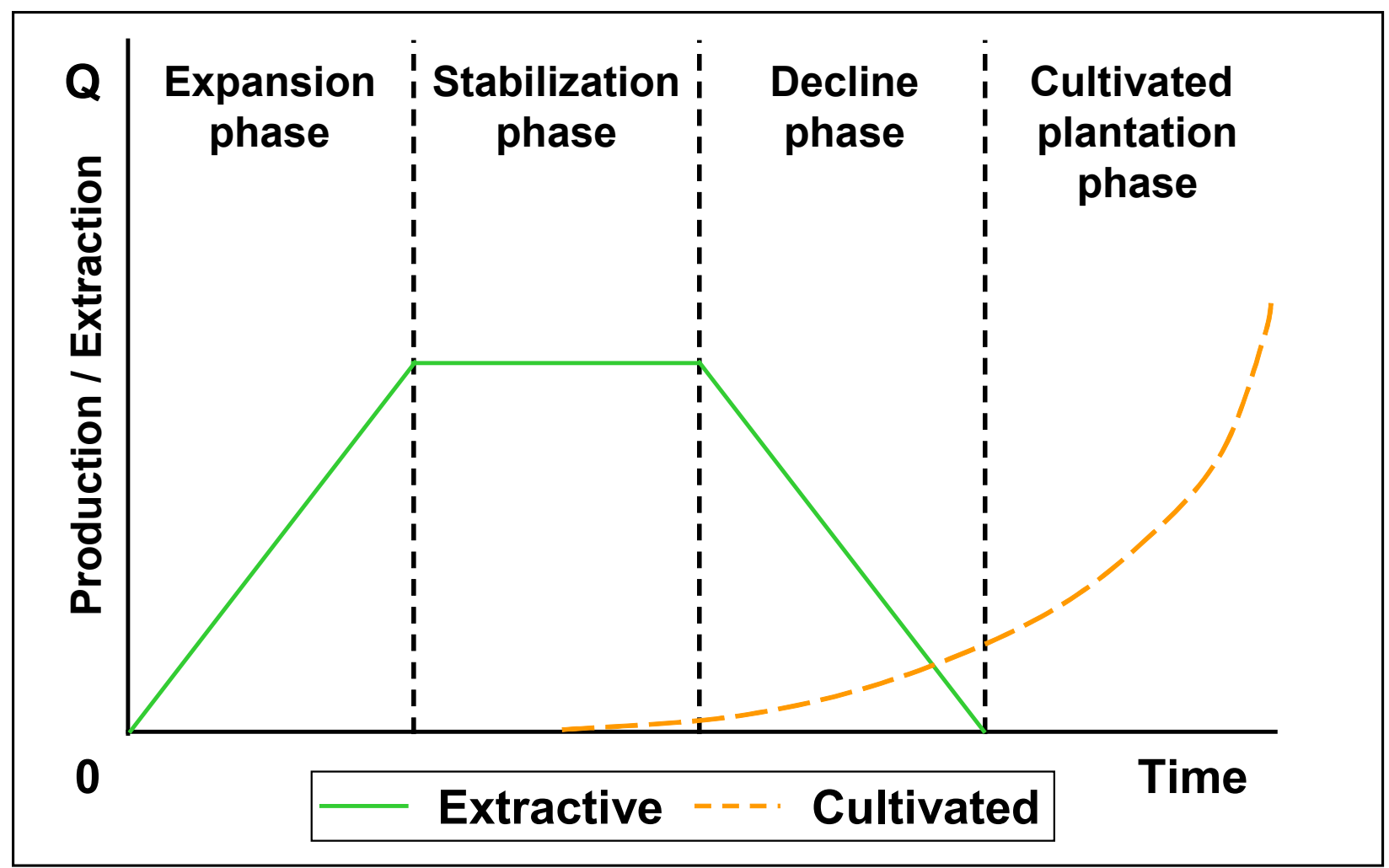

Figure 2. Homma's theoretical model of extractive production system dynamics (Homma 1996).

tion and development objectives of many protected areas translate into a comparative disadvantage for local communities in a commodity-based market where production is not bound by ecological constraints.

In light of the above factors, it is likely that the dominant production system for Chamaedorea palm will shift away from the wild-harvest of natural populations toward intensified cultivation under natural forest cover or artificial shade by external producers. Without intervention, Chamaedorea palm extraction will likely move into the disappearance phase of Homma's extractive cycle, as comparative advantage shifts from regions of low-cost production driven by natural abundance to particular producers with low-cost production driven by economies of scale. Perhaps it is unrealistic to expect this process to be averted, considering experiences with the intensified cultivation of other NTFP (e.g. coffee, rubber). Nevertheless, the diverse nature of NTFP extends to NTFP markets, and the negative livelihood and conservation impacts within and near conservation areas associated with shifting centers of Chamaedorea production may yet be mitigated.

\section{Chamaedorea certification}

Support for certification of Chamaedorea is based, in part, upon a recent survey of consumers that indicated a strong interest in a certified product (Current et al. 2003). Interest was strongest among church-based consumers, those who use palms for Palm Sunday services once a year and who may represent an additional source of demand throughout the year via the purchase of floral arrangements featuring certified palms. Formal standards for Chamaedorea certification do not yet exist and the feasibility of a full-scale specialty market has only been superficially tested via two regional pilot sales (CEC 2005, 2006). Moreover, it is not prudent to assume that expressed interests will necessarily translate into actual market demand (Forsyth et al. 1999, Kiker \& Putz 1997). Nevertheless, the promising results of these two sales have been interpreted by some as evidence that palm certification represents an appropriate and viable intervention for the sustained integration of conservation and development objectives. Given the nature and dynamics of extraction-based NTFP production systems, such a conclusion may be premature. Staking local forest conservation and development efforts on certified extraction may well lead to unintended conservation and development outcomes in the targeted regions.

Despite the many challenges associated with NTFP certification, several factors suggest that it may be a timely intervention worthy of further consideration. First, for all the past commercial success, present markets for Chamaedorea palm fronds appear to be stable, if not in the early stages of a gradual decline (personal communication, Jim Everett - Continental Floral Greens). This is supported by a recent survey of American wholesalers and retailers, which demonstrated that many perceive the 
use of Chamaedorea greens to be passé (CEC 2002). Moreover, with donor efforts directed toward the development of plantation-based Chamaedorea production, existing and emerging producers may soon find themselves in the position occupied by coffee producers in the 1990s: suffering record low prices resulting from an onslaught of surplus supply in the wake of donor-driven economic development projects (Belcher \& Schreckenberg 2003, Fitter $\&$ Kaplinsky 2000, Fritsch 2002). Certification may represent a means by which producers can insulate themselves from the negative price pressures found in the commodity markets.

A second, related issue is that production systems based on extraction are likely to disproportionately bear the high costs of low prices. This is underscored by the fact that plantation-grown Chamaedorea leaves are likely to have higher quality and uniformity as well as lower production costs per unit than wild leaves. Cost differences relate to economies of scale, lower levels of waste, and reduced transportation costs. These comparative and competitive disadvantages are already a reality for the many frustrated communities that cannot find buyers (or reasonable prices) for their consistent, but relatively small offerings of high quality palms. As has been the case with other NTFPs, the combination of commercial success and amenability to cultivation may hasten the departure of commercial palm production from the forest. If premiums can be obtained for certified management the cost burden borne by certified extractive systems could be mitigated.

Third, in regions where Chamaedorea production still depends on natural populations, reduced palm abundance and quality are symptoms of over-harvesting that have negatively impacted the perceived economic benefits of palm extraction. Intensified harvesting pressure comes from two directions: suppliers act to ensure that demand can be fulfilled while harvesters strive to maintain or improve their livelihoods. As shortages of market quality leaves from natural populations increase, stakeholders are becoming concerned that the extractive production system is approaching a critical threshold, described by Wiersum (1997) as the critical passage from extraction to early stages of cultivation outside of the forest. If history offers a lesson, it is reasonable to expect that cultivation under structurally-modified forest or artificial-shade may soon be the norm. At least one importer, Continental Floral Greens, anticipated these changes as early as 1989 , hedging wild supply with stock cultivated under natural forest cover. Certification may represent a means to bring forth the value in environmentally and socially sustainable production processes, thus eliminating the deleterious emphasis on high-volumes and low margins typically found in product-oriented commodity markets.

\section{Existing NTFP certification options}

Four categories of certification programs have been suggested as most relevant for NTFP applications (Ervin \& Mallet 2002, but also Vantomme \& Walter 2003, Walter 2002): 1) forest management; 2) social justice; 3) organic; and 4) product quality. Because the motivation for certification of Chamaedorea relates to social and environmental processes, rather than product quality concerns, product quality certification will not be addressed. Single certification programs rarely address all three of the dimensions of sustainability (society, environment, economy), instead most tend to focus on a single dimension while incorporating some standards for others. The fact that the numerous certification programs operate through the use of different, but often overlapping, standards represents an additional challenge to NTFP certification, but also suggests potential synergies (Vantomme \& Walter 2003).

\section{Forest management certification}

Forest management certification standards address the sustainable management of forests for timber harvesting and, to a lesser extent, other forest resources. Forest management standards prioritize management and ecological sustainability, but may include cursory standards or guidelines for social justice. Creating timber standards that are universally applicable for both temperate and tropical timber systems has been difficult; creating NTFP standards for myriad species and multiple forest environments may prove to be even more so. Consequently, while numerous certification programs for timber management exist, few offer more than marginal consideration of NTFP. The Forest Stewardship Council's "Draft Principle 11 " and "Generic Guidelines" (Box 2) have emerged as the most advanced and legitimate attempts at NTFP management standards (see Brown et al. 2002). Some examples of NTFP that have been certified under FSC standards include: maple syrup (USA), chicle resin (Mexico), Brazil nuts (Brazil, Bolivia, Peru), and açai palm hearts (Brazil).

Box 2. Generic Guidelines for NTFP (from Shanley et al. 2002):

1. Commitment to FSC Management Principles 1-10 and legal requirements;

2. Land tenure and use rights and responsibilities;

3. Forest management planning and monitoring;

4. Forest management practices;

5. Environmental impacts and biological conservation;

6. Social and cultural impacts;

7. Community and worker relations;

8. Benefits from the forest and economic viability;

9. Chain of custody in the forest, and;

10. Performance indicators and verifiers. 


\section{Wilsey \& Radachowsky - Keeping NTFPs in the Forest: Can certification provide an alternative to intensive cultivation?}

Forest management certification programs for timber have been extremely successful and continue to expand internationally. Noteworthy, however, is the limited representation of tropical forests relative to northern forests, the latter comprising $91 \%$ of certified forest area (UNECE 2004). Forest management certification has been most attractive to private managers of monoculture forest plantations common in North America and Europe, and less so to public managers of natural, highly diverse tropical forests. It would be unfair to consider this as a failure of forest management certification, but it would be unwise to ignore the potential implications for certification of NTFP. It is reasonable to expect that analogous NTFP standards emphasizing best management practices and sustainable yields would be adopted by managers of NTFP production systems with characteristics similar to those of certified timber operations. Chamaedorea agroforestry systems such as the one in Veracruz, Mexico will be equally or better suited to capture the benefits of certification, leaving communities currently dependent on wild harvest with a comparative disadvantage similar to their present situation.

\section{Social justice certification}

Social justice certification is perhaps better recognized by the market label, Fair Trade. At its most progressive, fair trade attempts to extend certification efforts by changing the social relations of production and exchange and by making the production process visible at the point of exchange (Hudson \& Hudson, 2003). Labor conditions and equitable benefit distribution are emphasized in fair trade certification. Environmental issues are included only as they relate to the worker environment, to the quality of the natural resource base as a component of the quality of life, and to economic sustainability. Examples of fair trade certified NTFP include: coffees and teas (various), chicle resin (Mexico), devil's claw (Namibia), and shea butter (Ghana).

Seven important social criteria are encompassed by most fair trade certification programs (Box 3). Like forest management certification, the fair trade movement has grown considerably over the past two decades. Its success has been fueled in large part by the success of certified coffee and cacao. Like forest management, fair trade certification seems most amenable to intensified production (agroforestry) systems such as coffee, tea, and cacao. While fair trade standards would likely provide significant social and economic benefits to Chamaedorea harvesters and their communities, it is unlikely that the environmental criteria would be adequate to ensure the conservation value of the forest production environment. In fact, the standards related to social security and worker benefits may actually favor the wage-labor environment of an agroforestry system or plantation over the intermittent labor patterns characteristic of wild-harvesting.
Box 3. Social criteria encompassed by

fair trade certifications (Mallet 2001):

1. Resource tenure;

2. Adequate and equitable benefits;

3. Safe working environment;

4. Impacts on indigenous communities;

5. Economic viability;

6. Child labor; and

7. Ethical marketing.

\section{Organic certification}

Organic certification refers to a holistic management system that promotes and enhances agro-ecosystem health (Walter 2002). Although organic emerged as a certification for agricultural crops, it is applicable to managed and wild-harvested forest products as well. In the organic context, a wild crop is defined as "any plant or portion of a plant that is collected or harvested from a site that is not maintained under cultivation or other agricultural management" (AMS 2002:365). Some examples of organic certified NTFP include coffee (various), berries (Finland), açai palm hearts (Brazil), and maple syrup (USA), among others.

Organic certification is perhaps the most recognized label among northern consumers. In an indirect tribute to the importance of organic standards, beginning in October 2002 the United States Department of Agriculture (USDA) assumed overarching responsibility for organic certification through its own National Organic Standards (AMS 2002). Because Chamaedorea is wild-harvested from a natural forest in the MBR, organic certification would likely be the easiest (although not necessarily the least expensive) to obtain. However, one important factor suggests that organic certification would not improve the comparative advantage of the wild-harvest production system. Organic certification emerged as a certification for agricultural systems and the standards are readily adopted by agroforestry operations. In fact, La Flor de Catemaco in Veracruz, Mexico already advertises their intensively cultivated palms as organic on the company's web page. As is the case with sustainable management and fair trade, an organic label would not likely be able to confer a comparative advantage on the wild-harvest production system.

\section{Discussion and conclusions}

Homma's model of extractive production system dynamics highlights the tenuous role of NTFP in the forest household livelihood systems; foreshadowing the eventual loss of extraction-based income resulting from shifting comparative advantage. The history of NTFP extraction in the MBR showcases this dynamic. The tapping of chicle latex peaked in the 1940s and the vast proportion of present demand is now supplied by synthetics (Dugelby 
1998). Allspice seed collection suffered a similar fate following the emergence of intensive plantations in the $\mathrm{Ca}-$ ribbean. Chamaedorea palm is presently the (economically) preeminent NTFP activity in the MBR, but experience suggests that its future role in local livelihoods and conservation may be limited. Certification is often suggested as a means to protect environmental commodities from unsustainable exploitation or to obtain a higher price for disadvantaged producers. Certification of Chamaedorea is presently being considered as a strategy for accomplishing both of these objectives in the MBR as well as other contexts (e.g. El Cielo Biosphere Reserve). The use of certification to achieve these ends, however, merely treats symptoms of a larger problem. Over-harvesting and low prices are by-products of production system dynamics. In the long run, neither sustainability standards nor price premiums will be of much importance should demand for extracted forest products decline precipitously in response to increased offerings from plantations. Those of us considering the appropriate role for NTFP certification as a component of an integrated conservation and development strategy would do better to ask, how can certification help to ensure that NTFP extraction remains an ecologically sustainable and economically viable source of income in the forest we are trying to conserve?

The adoption of existing certification options may mitigate over harvesting or facilitate price premiums for particular producers, but they are unlikely to prevent the outward migration of NTFP production from the forest. This is true for the simple reason that certification standards were not designed to keep production in a particular place. Instead, each program has been designed to capture the value of a single production process, be it sustainable management, social justice, or organic production. Forest conservation and livelihood improvement, in contrast, are site-specific. Having considered the dynamics of extractive production systems, the certification options presently available, and having recognized the site-specificity of conservation and development, we conclude that a new type of certification is required for NTFP that are components of integrated conservation and development programs. This new certification must capture the value of integrated conservation and development efforts, while at the same time recognizing the value of keeping production in a particular place. We envision three components of certification necessary to achieve sustained, integrated conservation and development benefits from NTFP.

First, NTFP certification will guarantee that forest products were harvested by individuals or groups living within the forest or by those directly responsible for the stewardship of the forest resources.

Integrated conservation and development represents a partnership between those who wish to conserve forest ecosystems and those who wish to benefit from forest resources. Sometimes these objectives are synergistic (win- win) and lead naturally to conservation and development (Wunder 2001). More often, trade-offs are required. Using certification to ensure that those who act as stewards of the resource are the ones who benefit from its products is a logical extension to ongoing integrated conservation and development strategies.

Second, NTFP certification will guarantee that forest product management and extraction is sustainable, and not detrimental to forest structure and ecological integrity.

Michon and de Foresta (1998) discuss "domestication" of ecosystems as an alternative to the domestication and intensified cultivation of individual forest products. Over the long-term, managed natural populations and enrichment plantings may serve forest conservation objectives while facilitating commercialization of NTFP. Certification should play a role in highlighting the conservation and livelihood value of these lesser yielding, but also less intensive management options.

Third, NTFP certification will guarantee that products originate from forests that are classified as working forests, or another integrated conservation and development classification.

Breaking from Homma's model requires that comparative advantage be conferred upon extractive production systems, even if they only represent a small fraction of total production. Using certification to help ensure a comparative advantage for sustainably-managed extractive systems by promoting markets for sustainably managed resources from working forests makes sense, and has the potential to yield additional synergies.

Demand already exists for "environmentally-friendly, socially-just" Chamaedorea palms (CEC 2005, 2006, Current et al. 2003): palms for which the price premium paid by consumers promotes forest conservation and rural livelihoods. Although sustainable management, fair trade, and organic certifications seem unlikely to be able to connect the value of production processes with the value of place-based conservation, they have played an important role in "removing the veil" (Hudson \& Hudson 2003) to bring production and management processes into product valuation, at least amongst certain consumers. Following the early model of product quality standards, these programs represent a second generation of third-party certification. The emergence of a NTFP certification may signify the beginning of a third generation of certifications; one able to capture the value of a multiple-objective production environment such as the community forestry and integrated conservation and development projects such as the community forest concessions of the MBR. 


\section{Wilsey \& Radachowsky - Keeping NTFPs in the Forest: Can certification provide an alternative to intensive cultivation?}

\section{Acknowledgements}

The authors are grateful for the support of the University of Florida School of Natural Resources and Environment and Department of Wildlife Ecology and Conservation. Partial financial support for ongoing research was provided by the Working Forests in the Tropics IGERT Program at the University of Florida. Projects developed by the North American Commission for Environmental Cooperation (CEC) and Center for Integrated Natural Resource and Agricultural Management (CINRAM) and Wildlife Conservation Society, Guatemala provided important background for this analysis. Roan McNab, Rony García, Jose Lopez, Eliberto Muñoz, Victor Hugo Ramos, and Kender Tut contributed to our understanding of forest concessions and Chamaedorea harvest in the MBR. Editorial thanks to Margo Stoddard, Bryan Endress, and an anonymous reviewer. We assume responsibility for any remaining errors and oversights.

\section{Literature Cited}

AMS. 2002. National Organic Program. Agricultural Marketing Service, United States Department of Agriculture. TMD-00-02-FR.

Anderson, P.J. \& F.E. Putz. 2002. Harvesting and conservation: Are both possible for the palm, Iriartea deltoidea? Forest Ecology and Management 170:271-283.

Arnold, J.E.M. \& M. Ruiz Pérez. 2001. Can non-timber forest products match tropical forest conservation and development objectives? Ecological Economics 39:437-447.

Belcher, B., M. Ruiz Pérez \& R. Achdiawan. 2005. Global patterns and trends in the use and management of commercial NTFPs: Implications for livelihoods and conservation. World Development 33:1435-1452.

Belcher, B.M. \& K. Schreckenberg. NTFP commercialization: a reality check. Paper presented to the World Forestry Congress, 2003.

Bridgewater, S.G.M., P. Pickles, N.C. Garwood, M. Penn, R.M. Bateman, H. Porter Morgan, N. Wicks \& N. Bol. 2006. Chamaedorea (Xate) in the greater Maya mountains and the Chiquibul Forest Reserve, Belize: An economic assessment of a non-timber forest product. Economic Botany 60:265-283.

Browder, J.O. 1992a. The limits of extractivism. Bioscience 42:174-183.

Browder, J.O. 1992b. Social and economic constraints on the development of market-oriented extractive reserves in Amazon rain forests. Pp.33-42 in Non-Timber Products from Tropical Forests: Evaluation of a conserva- tion and development strategy. Edited by D. Nepstad \& S. Schwartzman. The New York Botanical Gardens, New York.

Brown, L., D. Robinson \& M. Karmann. 2002. The Forest Stewardship Council and non-timber forest product certification: A discussion paper.

CEC. 2002. In search of a sustainable palm market in North America. Commission for Environmental Cooperation, Montreal, Quebec.

CEC. 2005. Churches celebrate 'eco-Palm' Sunday. TRIO. Commission for Environmental Cooperation.

CEC. 2006. Churches lend support to 'eco-palm' harvesters. TRIO. Commission for Environmental Cooperation.

Clay, J. 1992. Why Rainforest Crunch? Cultural Survival Quarterly 16:31-37.

Crook, C. \& R.A. Clapp. 1998. Is market oriented forest conservation a contradiction in terms? Environmental Conservation 25:131-145.

Current, D., E. Lassemo \& J.C. Cervantes. 2003. The potential market, and market and certification mechanisms for palms of the genus Chamaedorea. Commission for Environmental Cooperation of North America, CEC, Montreal.

Dankers, C. 2003. Environmental and Social Standards, Certification, and Labeling for Cash Crops. FAO, Rome.

Dove, M.R. 1993. A revisionist view of tropical deforestation and development. Environmental Conservation 20:17-24.

Dove, M.R. 1994. Marketing the rainforest: 'green' panacea or red herring? Analysis from the East-West Center 13:1-7.

Dugelby, B.L. 1998. Governmental and customary arrangements guiding chicle latex extraction in the Peten, Guatemala. Pp. 155-178 in Timber, Tourists, and Temples: Conservation and development in the Maya forest of Belize, Guatemala, and Mexico. Edited by R.B. Primack, D. Bray, H. A. Galletti \& I. Ponciano. Island Press, Washington, DC.

Dugelby, B.L. n.d. Getting the Goods out of the Woods. www.fadr.msu.ru/rodale/agseive/txt/vol5/1/art4.html

Endress, B.A., D.L. Gorchov, \& R.B. Noble. 2004a. Nontimber forest product extraction: effects of harvest and browsing on an understory palm. Ecological Applications $14: 1139-1153$. 
Endress, B.A., D.L. Gorchov, M.B. Peterson \& E. Padrón Serrano. 2004b. Harvest of the palm Chamaedorea radicalis, its effects of leaf production, and implications for sustainable management. Conservation Biology 18:1-9.

Endress, B.A., D.L. Gorchov \& E.J. Berry. 2006. Sustainability of a non-timber forest product: Effects of alternative leaf harvest practices over 6 years on yield and demography of the palm Chamaedorea radicalis. Forest Ecology and Management 234:181-191.

Ervin, J.B. \& P. Mallet. 2002. The rise of certification, the current state of the playing field for NTFP certification programs and future prospects. Pp. 7-19 in Tapping the Green Market - Certification and management of nontimber forest products. Edited by P. Shanley, A.R. Pierce, S.A. Laird \& A. Guillén. Earthscan, London, UK.

Finger-Stich, A. 2003. Community concessions and certification in the Maya Biosphere Reserve. Pp.165-178 in Social and Political Dimensions of Forest Certification. Edited by E. Meidinger, C. Elliot \& G. Oesten. Forstbuch, Germany.

Fitter, R. \& R. Kaplinsky. 2002. Can an agricultural "commodity" be de-commodified, and if so, who is to gain? Institute for Development Studies, Sussex.

Forsyth, K., D. Haley \& R. Kozak. 1999. Will Consumers Pay More for Certified Wood Products? Journal of Forestry 97:18-22.

Fort, M. \& L. Grandia. 1999. Population and environment in the Petén, Guatemala. Pp. 85-91 in Thirteen Ways of Looking at a Tropical Forest: Guatemala's Maya Biosphere Reserve. Edited by J.D. Nations. Conservation International, Washington, D.C.

Fritsch, P. 2002. Bitter brew: An oversupply of coffee beans deepens Latin America's woes." The Wall Street Journal 08 July 2002, p.A.1.

Homma, A.K.O. 1996. Modernization and technological dualism in the extractive economy in Amazonia. Pp.5981 in Current Issues in Non-Timber Forest Product Research. Edited by M. Ruiz Pérez \& J.E.M. Arnold. CIFOR, Bogor, Indonesia.

Hudson, I. \& M. Hudson. 2003. Removing the Veil? Organization \& Environment 16:413-431.

IRG. 2006. El rol de los productos naturales en el desarrollo rural, el alivo a la pobreza, y gobernabilidad en el manejo del recurso: el caso de la palma xate (Chamaedorea spp) en la región de Peten, Guatemala. International Resources Group, Washington, D.C.
Jones, F.A. \& D.L. Gorchov. 2002. Patterns of abundance and human use of the vulnerable understory palm, Chamaedorea radicalis (Arecaceae), in a montane cloud forest, Tamaulipas, Mexico. The Southwestern Naturalist 45:421-430.

Kiker, C.F. \& F.E. Putz. 1997. Ecological certification of forest products: economic challenges. Ecological Economics 20:37-51.

Laird, S.A. \& A. Guillén. 2002. Marketing issues. Pp.322336 in Tapping the Green Market - Certification and management of non-timber forest products. Edited by P. Shanley, A.R. Pierce, S.A. Laird, \& A. Guillén. Earthscan, London, UK.

Litow, P., M. Baker \& P.E. Hildebrand. 2001. Swidden agriculture in a forest society: livelihood strategies in the Maya Biosphere Reserve community of Uaxactún, Peten, Guatemala. Journal of International Agricultural and Extension Education 8(3): 49-54.

Mallet, P. 2001. Certifying the harvest: developments in NTFP certification. Pp 124-127 in Forest Communities in the Third Millennium. Proceedings of meeting, Kenora, Ontario October 1-4, 1999. Edited by I. Davidson-Hunt. US Forest Service.

Mallet, P. \& M. Karmann. 2001. Certification of NTFPs: an emerging field. ETFRN News: Non-Timber Forest Products. No. 32. European Tropical Forest Research Network.

Meidinger, E. 2003. Forest certification as a global civil society regulatory institution. Pp. 1-25 in Social and Political Dimensions of Forest Certification. Edited by E. Meidinger, C. Elliot \& G. Oesten. Forstbuch, Germany.

Michon, G. \& H. de Foresta. 1998. Agro forests as an alternative to pure plantations for the domestication and commercialization of NTFPs. FAO. Non-Wood Forest Products \#9: Domestication and commercialization of non-timber forest products in agroforestry systems. FAO, Rome.

Myers, N. 1983. Tropical moist forests: over exploited and under utilized? Forest Ecology and Management 6:5979.

Nations, J.D. 1992. Xateros, chicleros, and pimenteros: Harvesting renewable tropical forest resources in the Guatemalan Peten. Pp. 208-219 in Conservation of Neotropical forests: Working from traditional resource use. Edited by K.H. Redford \& C. Padoch. Colombia University Press, New York.

Nepstad, D. \& S. Schwartzman. 1992. Non-timber products from tropical forests: Evaluation of a conservation 


\section{Wilsey \& Radachowsky - Keeping NTFPs in the Forest: Can certification provide an alternative to intensive cultivation?}

and development strategy. The New York Botanical Gardens, New York.

Neumann, R.P. \& E. Hirsch. 2000. Commercialization of non-timber forest products: Review and analysis of research. CIFOR, Bogor, Indonesia.

Overdevest, C. \& M. Rickenbach. In-Press. Forest certification and institutional governance: An empirical study of Forest Stewardship Council certificate holders in the United States. Forest Policy and Economics.

Oyama, K. 1990. Variation in growth and reproduction in the neo tropical dioecious palm Chamaedorea tepejilote. Journal of Ecology 78:648-63.

Pickles, P. 2004. Eco-labeling Xate: the potential of certification to aid the development of a sustainable Belizean palm industry. M.S. Thesis, University of Edinborough.

Pierce, A.R. 1999. The challenges of certifying non-timber forest products. Journal of Forestry 97:34-37.

Pierce, A.R., P. Shanley \& S. Laird. 2003. Certification of non-timber forest products: limitations and implications of a market-based conservation tool. CIFOR, Bogor, Indonesia.

Porter Morgan, H. 2004. Towards the sustainable use of xaté palms in Belize (Chamaedorea spp.): the effects of defoliation on leaf growth and reproduction. Report to the UK Darwin Institute.

Radachowsky, J. \& V.H. Ramos. 2004. Effects of managed extraction on populations of the understory palm, Xate (Chamaedorea spp) in northern Guatemala. Wildlife Conservation Society, Guatemala.

Ramos, V.H. 2004. Monitoreo de los incendios forestales, Reserva de la Biosfera Maya, periodo 2003-2004. Wildlife Conservation Society, Guatemala.

Richards, M. 1993. Commercialization of Non-timber Forest Products in Amazonia. NRI Socio-economic Series. Natural Resources Institute, Chatham, U.K.

Ros-Tonen, M., W. Dijkman \& E.L. vanBuren. 1995. Commercial and Sustainable Extraction of Non-timber Forest Products. Tropenbos Foundation, Wageningen, Netherlands.

Sader, S. 1999. Deforestation trends in northern Guatemala: a view from space. Pp. 26-34 in Thirteen Ways of Looking at a Tropical Forest: Guatemala's Maya Biosphere Reserve. Edited by J.D. Nations. Conservation International, Washington, D.C.
Santos, J., F. Edouard \& E. Marshall. 2006. Mexican palm fronds for the US floral industry: opportunities and threats presented by a successful entrepreneur. Pp. 57-60 in Commercialization of Non-timber Forest Products: Factors influencing success. Lessons learned from Mexico and Bolivia and policy implications for decision-makers. Edited by E. Marshall, K. Schreckenberg \& A.C. Newton. UNEP, Cambridge, UK.

Shanley, P., A. Pierce \& S. Laird. 2005. Beyond Timber: Certification of non-timber forest products. Forest Trends, Washington, D.C.

Shanley, P., A.R. Pierce, S.A. Laird \& A. Guillén. 2002. editors of Tapping the Green Market - Certification and management of non-timber forest products. Earthscan, London, UK.

Simula, M. 1996. Economics of certification. Pp. 123-136 in Certification of Forest Products: Issues and Perspectives. Edited by V. Viana, E. Jamison, R. Donovan, C. Elliot \& H. Gholz. Island Press, Washington, D.C.

Ticktin, T. 2004. The ecological implications of harvesting non-timber forest products. Journal of Applied Ecology 41:11-21.

Trauernicht, C. \& T. Ticktin. 2005. The effects of non-timber forest product cultivation on the plant community structure and composition of a humid tropical forest in southern Mexico. Forest Ecology and Management 219:269-278.

UNECE. 2004. Forest Products Annual Market Review, 2003-2004. United Nations Economic Commission for Europe.

Vantomme, P. \& S. Walter. 2003. Opportunities and Challenges for Non-wood Forest Products Certification. FAO, Rome, Italy

Viana, V., E. Jamison, R. Donovan, C. Elliot \& H. Gholz. 1996. Certification of Forest Products: Issues and perspectives. Island Press, Washington, D.C..

Walter, S. 2002. Certification and benefit-sharing mechanisms in the field of non-wood forest products - an overview. Medicinal Plant Conservation 8. Newsletter of the IUCN Species Survival Commission, IUCN, Bonn.

Wiersum, K.F. 1997. Indigenous exploitation and management of tropical forest resources: an evolutionary continuum in forest-people interactions. Agriculture, Ecosystems, and Environment 63:1-16.

Wunder, S. 2001. Poverty alleviation and tropical forests - what scope for synergies. World Development 29(11):1917-1833. 
Zajfen, V. S. 2005. A Market Chain Analysis of Chamaedorea Palms: Prospects for Fair Trade labeling. M.S. thesis, lowa State University. 